\title{
PERBEDAAN KENAIKAN BERAT BADAN PADA BAYI DENGAN PEMBERIAN ASI EKSKLUSIF DAN ASI PARSIAL DI PUSKESMAS KALIDONI PALEMBANG
}

\author{
Noviani Elsira \\ Prodi DIII Kebidanan STIKES Mitra Adiguna Palembang \\ Komplek Kenten Permai Blok J No 9-12 Bukit Sangkal Palembang 30114 \\ Email : essi.noviani@yahoo.com
}

\begin{abstract}
Abstrak
Air Susu Ibu (ASI) merupakan cairan biologis kompleks yang mengandung semua nutrient yang diperlukan untuk tumbuh kembang anak. Terkadang masih banyak ibu yang memberi tambahan susu formula pada bayinya yang cukup bulan dan sehat karena merasa ASInya belum keluar atau kurang. Tujuan penelitian ini adalah diketahui ada perbedaan kenaikan berat badan pada bayi dengan pemberianASI Eksklusif dan ASI Parsial di Puskesmas Kalidoni Palembang tahun 2018. Desain penelitian ini menggunakan study comparative.Populasi pada penelitian ini adalah seтиa ibu yang memiliki bayi usia 7-12 bulan di Puskesmas Kalidoni Palembang pada bulan April tahun 2018 dengan jumlah sampel sebanyak 30 orang. Hasil penelitian didapatkan rata-rata pertambahan berat badan bayi yang diberi ASI Ekslusif adalah 4260 gram, sedangkan rata-rata pertambahan berat badan bayi yang diberi ASI Parsial adalah 4580. Hasil uji statistik didapatkan adaperbedaan kenaikan berat badan pada bayi dengan pemberian ASI eksklusif dan ASI parsial di Puskesmas Kalidoni Palembang tahun 2018 dengan nilai $p$ value $0,000<\alpha(0,05)$. Saran diharapkan agar tenaga kesehatan khususnya bidan di Puskesmas Kalidoni Palembang lebih meningkatkan informasi terkait tentang maanfaat dan pentingnya pemberian ASI eksklusif untuk kenaikan berat badan bayi yang optimal.
\end{abstract}

Kata Kunci : ASI Eksklusif, ASI Parsial

Bahan Bacaan : $20(2009-2017)$

\begin{abstract}
Abtract
Human milk is a complex biological liquid that contains all the nutrients needed for child's development. Some women, compliment breastfeeding with formula milk to their babies because they feel it is not enough. The purpose of this study is to know if there are differences in weight gain in infants with exclusive and partial breastfeeding at Kalidoni Community Health Center of Palembang in 2018. It is a comparative study the population of which is all mothers who had babies aged 7-12 months at the Health Center in April 2018 with a total sample of 30 people. The results show that the average weight gain of infants who were given exclusive breastfeeding was 4260 grams, while the average weight gain of infants who were given partial breastfeeding was 4580. The statistical test results showed that there were significant differences in weight gain in infants with exclusive and partial breastfeeding with $p$ value of $0,000<\alpha(0.05)$. It is expected that health workers, especially midwives improve related information about the benefits and importance of exclusive breastfeeding for optimal baby weight gain.
\end{abstract}

Keywords

:Exclusive breastfeeding, partial breast milk

References

: 20 (2009-2017) 


\section{PENDAHULUAN}

Air Susu Ibu (ASI) merupakan cairan biologis kompleks yang mengandung semua nutrient yang diperlukan untuk tumbuh kembang anak.Sifatnya yang sangat mudah diserap oleh tubuh bayi, menjadikan nutrisi utama yang paling memenuhi persyaratan untuk tumbuh kembang bayi. Air Susu Ibu (ASI) merupakan faktor yang paling menentukan dalam proses pertumbuhan dan perkembangan bagi bayi usia $0-6$ bulan. Sebelum mencapai usia 6 bulan, sistem pencernaan bayi belum mampu mencerna makanan selain ASI. Oleh karena itu, pemberian ASI secara eksklusif adalah pilihan tepat dan sangat dianjurkan untuk jangka 6 bulan (Damayanti, 2014).

Keunggulan ASI sebagai nutrisi bayi telah banyak dipelajari dan dibuktikan oleh para peneliti sehingga Organisasi Kesehatan Dunia (WHO) merekomendasikan ASI eksklusif untuk bayi sampai berumur 6 bulan dan kemudian dilanjutkan bersama makanan pendamping ASI sampai bayi berumur 2 tahun atau lebih. Bagi ibu yang melahirkan di fasilitas kesehatan, peraturan rumah bersalin / rumah sakit serta sikap dan dukungan petugas kesehatan sangat mempengaruhi keberhasilan mereka menyusui di kemudian hari. Apabila secara rutin diberikan informasi dan motivasi kepada ibu hamil, diberi kesempatan untuk inisiasi menyusu dini, kemudian didukung dan dibantu mempraktekkan teknik menyusui yang benar selama ibu dirawat, kemungkinan ibu akan berhasil menyusui eksklusif sehingga tambahan pengganti ASI tidak diperlukan (Marnoto, 2013).

Buruknya pemberian ASI Eksklusif, terbatasnya persediaan pangan di tingkat rumah tangga serta terbatasnya akses balita sakit terhadap pelayanan kesehatan yang berkualitas menyebabkan lima juta bayi menderita gizi kurang. Padahal kekurangan gizi yang terjadi pada bayi akan berdampak pada gangguan psikomotor, kognitif dan sosial serta secara klinis terjadi gangguan pertumbuhan bahkan kematian. Menurut World Health Organization (WHO), sekitar 132 bayi meninggal setiap tahunnya sebelum usia satu tahun, dimana lebih dari setengahnya terkait dengan gizi kurang dan gizi buruk serta penyakit infeksi (Munir, 2013).

Berdasarkan data Kementrian Kesehatan Republik Indonesia (Kemenkes RI), cakupan pemberian ASI pada bayi usia 0-6 bulan dari 3.561.617 bayi, yang mendapatkan ASI hanya 1.983 .066 bayi $(55,7 \%)$. Cakupan pemberian
ASI pada bayi usia 0-6 bulan tertinggi terdapat pada Provinsi Nusa Tenggara Barat sebanyak 80.412 bayi $(86,9 \%)$, sedangkan cakupan pemberian ASI pada bayi usia 0-6 bulan terendah terdapat pada Provinsi Sulawesi Utara sebanyak 9.657 bayi (263\%)(Kemenkes RI, 2016).

Cakupan pemberian ASI Eksklusif pada bayi usia 0-6 bulan di Provinsi Sumatera Selatan berdasarkan data Kementrian Kesehatan Republik Indonesia (Kemenkes RI)dari 135.874 bayi yang mendapat ASI hanya 81.868 bayi (60,3\%) (Kemenkes RI, 2016).

Berdasarkan data Dinas Kesehatan Kota Palembang, cakupan pemberian ASI Eksklusif pada bayi usia 0-6 bulan tahun 2015 sebanyak 9.492 bayi $(72,9 \%)$ dari 13.018 bayi, tahun 2016 cakupan pemberian ASI Ekslusif pada bayi usia $0-6$ bulan mengalami penurunan 8.572 bayi

$(68,5 \%)$ dari 12.509 bayi dan tahun 2017 cakupan pemberian ASI Ekslusif pada bayi usia 0-6 bulan mengalami kenaikan sebanyak 8.015 bayi $(73,2 \%)$ dari 10.937 bayi (Dinkes Kota Palembang, 2017).

Pemberian ASI saja pada bayi tanpa tambahan makanan atau minuman selama 6 bulan pertama dapat membantu pertambahan berat badan maupun panjang badan, karena komponen ASI sesuai dengan kebutuhan bayi. ASI mengandung zat gizi dan vitamin yang diperlukan oleh tubuh bayi antara lain LPUFAs (long chain polyunsaturated fatty), protein, lemak, karbohidrat, laktosa, zat besi, mineral, sodium, kalsium, fosfor dan magnesium, vitamin, taurin, laktobacillus, laktoferin dan lisosim serta air. Oleh karena itu, ASI dalam jumlah cukup dapat memenuhi kebutuhan gizi bayi selama enam bulan pertama setelah kelahiran. Setelah 6 bulan berikan makanan tambahan dan tetap teruskan pemberian ASI sampai usia 2 tahun (Yenie, 2015)

Pertambahan berat badan bayi usia 6 bulan mengalami penambahan 150-210 gram/minggu dan panjang badan lahir normal adalah 45-50 cm, berdasarkan kurva pertambahan berat badan yang diterbitkan oleh National Center for Health Statistics (NCHS). Berat badan gram, apabila kurang dari 2.500 gram dikatakan bayi memiliki berat badan lahir rendah (BBLR), sedangkan bila lebih dari 3.500 gram dikatakan makrosomia. Setiap bulan bayi akan mengalami penambahan panjang badan sekitar 2,5 cm. Pada masa bayi-balita, berat 
badan dan panjang badan digunakan untuk mengetahui pertumbuhan fisik dan status gizi yang erat kaitannya dengan pertumbuhan bayi (Hidayat dalam Yenie, 2015).

Terkadang masih banyak ibu yang memberi tambahan susu formula pada bayinya yang cukup bulan dan sehat karena merasa ASInya belum keluar atau kurang. Salah satu penyebab adalah kurangnya informasi bahwa memberi susu formula terutama pada hari hari pertama kelahiran mungkin mengganggu produksi ASI, bonding, dan dapat menghambat suksesnya menyusui dikemudian hari. Bayi yang diberi formula akan kenyang dan cenderung malas untuk menyusu sehingga pengosongan payudara menjadi tidak baik. Akibatnya payudara menjadi bengkak sehingga ibu kesakitan, dan akhirnya produksi ASI memang betul menjadi kurang (Marnoto, 2013).

ASI parsial (partial breastfeeding) adalah memberikan makanan pada bayi dengan cara sebagian menyusui sebagian lagi susu buatan, sereal, atau makanan lain. Sedangkan WHO mendefinisikan menyusui parsial adalah menyusui bayi serta diberikan makanan buatan selain ASI, baik susu formula, bubur atau makanan lainnya sebelum bayi berumur 6 bulan baik diberikan secara kontinyu, maupun diberikan sebagai makanan prelaktal (Norma, 2015).

Bayi usia 0-6 bulan yang tidak diberi ASI Eksklusif cenderung lebih banyak yang mengalami kelebihan berat badan dengan ratarata pertambahan/kenaikan 1.240 gram/bulan pada usia 0-3 bulan. Hal ini dapat dinyatakan bahwa berat badan bayi yang mendapat ASI eksklusif lebih ringan dibanding bayi yang mendapat ASI non eksklusif/parsial sampai usia 6 bulan. Hal ini bukan berarti bahwa berat badan yang lebih besar pada bayi yang mendapat ASI non eksklusif/parsial lebih baik dibanding bayi yang mendapat ASI eksklusif (Norma, 2015).

Berdasarkan data Puskesmas Kalidoni Palembang, cakupan pemberian ASI Eksklusif tahun 2015 sebesar 173 bayi $(78,6 \%)$ dari 220 bayi, tahun 2016 mengalami kenaikan sebesar 237 bayi $(90,4 \%)$ dari 262 bayi dan tahun 2017 mengalami penurunan sebesar 542 bayi $(74,4 \%)$ dari 728 bayi (Puskesmas Kalidoni Palembang, 2017).

Berdasarkan latar belakang diatas, peneliti tertarik untuk melakukan penelitian dengan judul "Perbedaan Kenaikan Berat Badan Pada Bayi Dengan Pemberian ASI Eksklusif
Dan ASI Parsial Di Puskesmas Kalidoni Palembang Tahun 2018”.

\section{METODE PENELITIAN \\ Ruang Lingkup Penelitian}

Penelitian dilakukan pada semua ibu yang memiliki bayi usia 7-12 bulan di Puskesmas Kalidoni Palembang tahun 2018.

\section{FormatPenelitian}

Penelitian ini merupakan penelitian kuantitatif dengan menggunakan study comparative. Penelitian ini peneliti akan membandingkan kenaikan berat badan pada bayi yang mendapat ASI Eksklusif dengan ASI Parsial di Puskesmas Kalidoni Palembang tahun 2018.

\section{Waktu Penelitian}

Penelitian ini dilakukan pada tanggal 418 April tahun 2018.

\section{Tempat Penelitian}

Penelitian ini dilakukan di Puskesmas Kalidoni Palembang.

\section{Data dan Cara Pengumpulan Data Data Primer}

Dalam penelitian ini data primer didapat dari observasi dan wawancara secara langsung terhadap ibu yang memiliki bayi usia 7-12 bulan dan melihat KMS.

\section{Cara Pengumpulan Data}

Pengumpulan Data pada penelitian ini menggunakan wawancara dengan kuesioner yang dilakukan secara langsung kepada responden di Puskesmas Kalidoni Palembang.

\section{Populasi dan Sampel Populasi}

Populasi adalah keseluruhan objek penelitian atau objek yang diteliti (Notoatmodjo, 2012).

Populasi pada penelitian ini adalah semua ibu yang memiliki bayi usia 7-12 bulan di Puskesmas Kalidoni Palembang pada bulan April tahun 2018.

\section{Sampel}

Dalam penelitian ini pengambilan jumlah sampel di tentukan berdasarkan teori Notoatmodjo (2012) yang menyatakan bahwa apabila suatu populasi terdiri dari unit yang 
mempunyai karakteristik yang berbeda-beda atau heterogen,maka teknik pengambilan sampel yang cepat digunakan adlah stratified sampling. Hal ini dilakukan dengan cara mengidentifikasi karakteristik umum dari anggota populasi, kemudian menentukan strate atau lapisan dari jenis karakteristik unit-unit tersebut. Setelah ditentukan stratanya barulah dari masing-masing strata diambil sampel yang mewakili strata tersebut secara random atau acak, misalkan tiap strata diambil dengan jumlah sampel yang sama.

Sampel dalam penelitian ini diambil dari sebagianibu yang memiliki bayi usia 7-12 bulan di Puskesmas Kalidoni Palembang pada bulan April tahun 2018 yang berjumlah 30 orang yaitu 15 orang ibu yang memberikan bayinya ASI Eksklusif dan 15 orang ibu yang memberikan bayinya ASI Parsial.

\section{Teknik Pengambilan Sampel}

Pengambilan sampel pada penelitian ini dilakukan dengan caranon probability sampling menggunakan metode purposive sampling yaitu pengambilan sampel didasarkan pada suatu pertimbangan tertentu yang dibuat oleh peneliti sendiri berdasarkan ciri atau sifat-sifat populasi yang sudah diketahui sebelumnya (Notoatmodjo, 2012).

Kriteria Inklusi:

1. Ibu yang memiliki bayi usia 7-12 bulan

2. Ibu yang membawa KMS pada saat ke puskesmas

3. Kooperatif dan dapat berkomunikasi dengan baik

4. Bersedia menjadi responden dalam penelitian

Kriteria Eksklusi:

1. Kondisi ibu atau bayi sedang tidak sehat atau tidak memungkinkan untuk di wawancarai

\section{Teknik Analisis Data Analisa Bivariat}

Pada penelitian ini, analisis bivariat dilakukan dengan terlebih dahulu melakukan uji normalitas data primier menggunakan uji kolmogorov-smirnov dengan ketentuan jika $p$ value $\geq 0,05$ berarti data terdistribusi normal dan jika jika $p$ value $<0,05$ berarti data tidak terdistribusi normal.Selanjutnya untuk uji pengaruh menggunakan uji statistik tidak berpasangan (Independent Samples $t$ Test) dengan tingkat kemaknaan $\alpha=0,05$ bila data terdistribusi normaldan Mann Whitney Test bila data tidak terdistribusi normal dengan ketentuan jika $p$ value $<0,05$ berarti ada perbedaan dan jika jika $p$ value $\geq 0,05$ berarti tidak ada perbedaan (Dahlan, 2012).

\section{HASIL PENELITIAN DAN PEMBAHASAN}

\section{Hasil Penelitian}

\section{Uji Normalitas}

Sebelum dilakukan analisis dengan uji $\mathrm{t}$ data harus memenuhi syarat uji normalitas.Dalam uji normalitas jika sampel berjumlah $\leq 50$ maka menggunakan shapirowilk dan jika jumlah sampel > 50 maka menggunakan

kolmogorov-smirnov (Pamungkas, 2016). Uji normalitas dalam penelitian ini digunakan uji Shapiro-Wilk. Data dikatakan berdistribusi normal jika nilai signifikan (2-tailed) $>0,05$.

\section{Tabel 4.1}

Uji Normalitas Perbedaan Kenaikan Berat Badan Pada Bayi Dengan Pemberian ASI Eksklusif Dan ASI Parsial Di Puskesmas Kalidoni Palembang Tahun 2018

\begin{tabular}{lccc}
\hline \multicolumn{1}{c}{ Variabel } & Shapiro-Wilk & P.Value & Status \\
\hline ASI Eksklusif & 0,895 & 0,079 & Normal \\
\cline { 2 - 4 } ASI Parsial & 0,889 & 0,065 & Normal \\
\hline
\end{tabular}

Berdasarkan tabel 4.1 diatas di ketahui nilai $P$ value uji Shapiro-Wilk pada kelompok ASI Eksklusif sebesar 0,079 $>\alpha(0,05)$ dan pada kelompok ASI Parsial sebesar 0,065 $>\alpha(0,05)$. Karena semua kelompok $>\alpha(0,05)$ maka kedua kelompok sama-sama berdistribusi normal berdasarkan uji Shapiro-Wilk.

\section{Analisis Univariat}

Tabel 4.2
9istribusi Rata-Rata Pertambahan Berat Badan Bayi Usia 7 Bulan
Yang Diberi ASI Eksklusif dan Yang Diberi ASI Parsial
Puskesmas Kalidoni Palembang Tahun 2018

Berdasarkan tabel 4.2 diketahui bahwa rata-rata pertambahan berat badan bayi yang diberi ASI Ekslusif adalah 4260 gram $(95 \% \mathrm{CI}$ : 4182,24-4337,76), median 4300 gram dengan standar deviasi 140,408 . Berat badan terendah adalah 4000 gram dan berat badan tertinggi adalah 4500 gram. Dari hasil estimasi interval dapat disimpulkan bahwa 95\% diyakini bahwa rata-rata pertambahan berat badan pada bayi 
yang diberi ASI eksklusif adalah diantara 4182,24 gram sampai dengan 4337,76 gram.

Hasil analisis didapatkan rata-rata pertambahan berat badan bayi yang diberi ASI Parsial adalah 4580 gram (95\% CI: 4461,234698,77), median 4600 gram dengan standar deviasi 214,476 . Berat badan terendah adalah 4300 gram dan berat badan tertinggi adalah 4900 gram. Dari hasil estimasi interval dapat disimpulkan bahwa 95\% diyakini bahwa ratarata pertambahan berat badan pada bayi yang diberi ASI parsial adalah diantara 4461,23 gram sampai dengan 4698,77 gram.

\section{Analisis Bivariat}

Analisa bivariat ini dilakukan untuk membandingkan kenaikan berat badan bayi yang diberi ASI Eksklusif dan kenaikan berat badan bayi yang diberi ASI parsial dengan uji statistik yang sesuai dengan tujuan penelitian, yaitu uji independent $t$-test sampel dengan taraf signifikan $\alpha=0,05$ dimana ketentuannya adalah jika nilai $p$ value $>\alpha(005)$ berarti tidak ada perbedaan dan jika $p$ value $<\alpha(005)$ berarti ada perbedaan.

Jumlah responden dalam penelitian ini adalah 30 responden yang dibagi dalam 2 kelompok yaitu 15 orang ibu yang memberikan bayinya ASI Eksklusif dan 15 orang ibu yang memberikan bayinya ASI Parsial. Setelah di dapat data dari analisis univariat dan perhitungan menggunakan uji-t (independent sample $t$-test), maka di peroleh:

Tabel 4.3

Hasil Analisis Uji Independent Sampel t Test Perbedaan Kenaikan Berat Badan Pada Bayi Dengan Pemberian ASI Eksklusif Dan ASI Parsial Di Puskesmas Kalidoni Palembang Tahun 2018

\begin{tabular}{|c|c|c|c|c|c|}
\hline BB Bayi & Mean & SD & SE & $\begin{array}{c}\mathbf{P} \\
\text { Value }\end{array}$ & $\mathbf{N}$ \\
\hline ASI Eksklusif & 4260 & 140,408 & 36,253 & \multirow{2}{*}{0,000} & 15 \\
\hline ASI Parsial & 4580 & 214,476 & 55,377 & & 15 \\
\hline
\end{tabular}

Berdasarkan tabel 4.3 diatas diketahui rata-rata pertambahan berat badan bayi yang diberi ASI eksklusif adalah 4260 gram dengan standar deviasi 140,408 gram, sedangkan untuk bayi yang diberi ASI parsial rata-rata pertambahan berat badan bayi adalah 4580 gram dengan standar deviasi adalah 214,476 gram. Perbedaan nilai rata-rata pertambahan berat badan antara bayi yang diberi ASI eksklusif dan bayi yang di beri ASI parsial adalah 320 . Hasil uji statistik didapatkan nilai $\mathrm{p}$ value $=0,000<\alpha$ $(0,05)$ berarti HO ditolak. Terlihat bahwa ada perbedaan yang signifikan pertambahan berat badan antara bayi yang diberi ASI Ekslusif dibandingkan dengan bayi yang diberi ASI parsial dilihat dari nilai $p$ value $=0,000<\alpha$ $(0,05)$.

\section{Pembahasan \\ Kenaikan Berat Badan Bayi Yang Diberi ASI Eksklusif dan ASI Parsial Di Puskesmas Kalidoni Palembang Tahun 2018}

Berdasarkan analisis univariat diketahui rata-rata pertambahan berat badan bayi yang diberi ASI Ekslusif adalah 4260 gram (95\% CI: 4182,24-4337,76), median 4300 gram dengan standar deviasi 140,408 . Berat badan terendah adalah 4000 gram dan berat badan tertinggi adalah 4500 gram. Sedangkan rata-rata pertambahan berat badan bayi yang diberi ASI Parsial adalah 4580 gram (95\% CI: 4461,234698,77), median 4600 gram dengan standar deviasi 214,476 . Berat badan terendah adalah 4300 gram dan berat badan tertinggi adalah 4900 gram.

Dari 15 responden yang bayinya diberikan ASI Eksklusif sebagian besar mengalami kenaikan berat badan normal sebanyak 10 responden $(66,7 \%)$, hal yang sama terjadi pada 15 responden yang diberikan susu formula sebagian besar mengalami kenaikan berat badan normal sebanyak 10 responden $(66,7 \%)$.

Hasil penelitian ini sejalan dengan penelitian yang dilakukan Norma (2015), yang berjudul perbedaan kenaikan berat badan pada bayi yang mendapat ASI Eksklusif dengan ASI Parsial di Puskesmas Jetis Kota. Hasil uji statistik menunjukkan kenaikan berat badan 210 gram lebih tinggi pada bayi yang mendapat ASI eksklusif, kenaikan berat badan bayi yang mendapat ASI eksklusif adalah 8.200 gram dan 7.990 gram pada bayi yang mendapat ASI parsial.

Hal ini sesuai dengan pernyataan Yenie (2015), yang menyatakan bahwa pemberian ASI saja pada bayi tanpa tambahan makanan atau minuman selama 6 bulan pertama dapat membantu pertambahan berat badan maupun panjang badan, karena komponen ASI sesuai dengan kebutuhan bayi. ASI mengandung zat gizi dan vitamin yang diperlukan oleh tubuh bayi antara lain LPUFAs (long chain polyunsaturated fatty), protein, lemak, karbohidrat, laktosa, zat besi, mineral, sodium, kalsium, fosfor dan magnesium, vitamin, taurin, laktobacillus, laktoferin dan lisosim serta air. 
Oleh karena itu, ASI dalam jumlah cukup dapat memenuhi kebutuhan gizi bayi selama enam bulan pertama setelah kelahiran. Setelah 6 bulan berikan makanan tambahan dan tetap teruskan pemberian ASI sampai usia 2 tahun.

$$
\text { Menurut Norma (2015), yang }
$$
menyatakan bahwa sumber kalori utama dalam ASI adalah lemak. Lemak ASI mudah dicerna dan diserap oleh bayi karena ASI mengandung enzim lipase yang mencerna lemak trigliserida menjadi digliserida, sehingga sedikit sekali lemak yang tidak diserap oleh sistem pencernaan bayi. Sedangkan susu formula (MP-ASI) tidak mengandung enzim karena enzim akan rusak bila dipanaskan. Itu sebabnya, bayi akan sulit menyerap lemak susu formula dan menyebabkan bayi menjadi diare serta menyebabkan penimbunan lemak yang pada akhirnya akan berakibat kegemukan (obesitas) pada bayi.

Berdasarkan hasil penelitian dan pembahasan diatas peneliti berasumsi bahwa pemberian ASI Eksklusif pada bayi usia 0-6 bulan akan memberikan kenaikan berat badan yang normal. Hal ini karena ASI Eksklusif telah mengandung zat gizi dan vitamin yang dibutuhkan oleh bayi hingga usia 6 bulan selain itu kandungan lemak yang terdapat dalam ASI Eksklusif sangat rendah sehingga tidak menimbulkan kegemukan pada bayi.

\section{Perbandingan Penambahan Berat Badan Bayi Yang Diberi ASI Eksklusif dan Bayi Yang Diberi ASI Parsial Di Puskesmas Kalidoni Palembang Tahun 2018}

Berdasarkan analisis bivariat diketahui rata-rata pertambahan berat badan bayi yang diberi ASI eksklusif adalah 4260 gram dengan standar deviasi 140,408 gram, sedangkan untuk bayi yang diberi ASI parsial rata-rata pertambahan berat badan bayi adalah 4580 gram dengan standar deviasi adalah 214,476 gram. Perbedaan nilai rata-rata pertambahan berat badan antara bayi yang diberi ASI eksklusif dan bayi yang di beri ASI parsial adalah 320 . Hasil uji statistik didapatkan nilai $\mathrm{p}$ value $=0,000<\alpha$ $(0,05)$ berarti HO ditolak. Terlihat bahwa ada perbedaan yang signifikan pertambahan berat badan antara bayi yang diberi ASI Ekslusif dibandingkan dengan bayi yang diberi ASI parsial dilihat dari nilai $p$ value $=0,000<\alpha$ $(0,05)$.

Hasil penelitian ini sejalan dengan penelitian yang dilakukan Norma (2015), yang berjudul perbedaan kenaikan berat badan pada bayi yang mendapat ASI Eksklusif dengan ASI Parsial di Puskesmas Jetis Kota. Hasil uji statistik menunjukkan kenaikan berat badan 210 gram lebih tinggi pada bayi yang mendapat ASI eksklusif, kenaikan berat badan bayi yang mendapat ASI eksklusif adalah 8.200 gram dan 7.990 gram pada bayi yang mendapat ASI parsial.

Hal ini sesuai dengan teori Roesli (2015), yang menyatakan bahwa pemberian ASI saja pada bayi tanpa tambahan makanan atau minuman selama 6 bulan pertama dapat membantu pertambahan berat badan maupun panjang badan, karena komponen ASI sesuai dengan kebutuhan bayi. ASI mengandung zat gizi dan vitamin yang diperlukan oleh tubuh bayi antara lain LPUFAs (long chain polyunsaturated fatty), protein, lemak, karbohidrat, laktosa, zat besi, mineral, sodium, kalsium, fosfor dan magnesium, vitamin, taurin, laktobacillus, laktoferin dan lisosim serta air. Oleh karena itu, ASI dalam jumlah cukup dapat memenuhi kebutuhan gizi bayi selama enam bulan pertama setelah kelahiran. Setelah 6 bulan berikan makanan tambahan dan tetap teruskan pemberian ASI sampai usia 2 tahun.

Hasil penelitian ini sejalan dengan penelitian yang dilakukan Yenie (2015) yang berjudul study komparatif pemberian ASI Eksklusif danpemberian PASI terhadap pertambahan berat dan panjang badan pada bayi umur 6 bulan di Posyandu wilayah kerja Puskesmas Hajimena Tanjung Karang. Hasil penelitian didapatkan bahwa rata-rata pertambahan BB pada bayi yang diberi ASI eksklusif adalah 4043,27 gram $(95 \% \quad \mathrm{Cl}$ : 410,046-711,108), median 4100,00 gram, dengan standar deviasi 334, 17 gram. BB terendah adalah 3100 gram dan BB yang tertinggi adalah 4700 gram. Hasil analisis didapatkan rata-rata pertambahan BB pada bayi yang diberi PASI meningkat menjadi 4603,85 gram (95\% Cl: 409,929-711,225), median 4700,00 gram dan standar deviasi 433,39 gram. BB terendah 3300 gram dan BB yang tertinggi 6000 gram. Hasil uji statistik didapatkan nilai $p$ $=0,000$ ( $\mathrm{p}$ value < 0,05), berarti HO. Ditolak. Terlihat ada perbedaan yang signifikan pertambahan $\mathrm{BB}$ antara bayi yang diberi ASI eksklusif dibandingkan dengan bayi yang diberi PASI oleh ibunya.

Hal ini sesuai pernyataan dalam Norma (2015), yang menyatakan bahwa sumber kalori utama dalam ASI adalah lemak. Lemak ASI 
mudah dicerna dan diserap oleh bayi karena ASI mengandung enzim lipase yang mencerna lemak trigliserida menjadi digliserida, sehingga sedikit sekali lemak yang tidak diserap oleh sistem pencernaan bayi. Sedangkan susu formula (MPASI) tidak mengandung enzim karena enzim akan rusak bila dipanaskan. Itu sebabnya, bayi akan sulit menyerap lemak susu formula dan menyebabkan bayi menjadi diare serta menyebabkan penimbunan lemak yang pada akhirnya akan berakibat kegemukan (obesitas) pada bayi. Selain itu, bayi yang mendapat makanan lain, misalnya nasi lumat atau pisang hanya akan mendapat banyak karbohidrat sehingga zatgizi yang masuk tidak seimbang. Terlalu banyak karbohidrat menyebabkan anak lebih mudah menderita kegemukan dengan segala akibatnya.

Hasil penelitian ini sejalan dengan penelitian yang dilakukan Utami (2015) yang berjudul studi komparasi kenaikan berat badan pada bayi (0-6 bulan) yang diberi ASI eksklusif dengan bayi yang diberi susu formula di Polindes Drajat dan Banjaranyar Wilayah Kerja Puskesmas Baureno Kabupaten Bojonegoro. Hasil penelitian didapatkan dari 17 responden yang diberikan ASI Eksklusif lebih dari sebagian mengalami kenaikan berat badan normal sebanyak 9 responden (52,90\%), sedangkan dari 14 responden yang diberikan susu formula sebagian besar mengalami kenaikan berat badan tidak normal sebanyak 12 responden $(85,72 \%)$.

Hal serupa dinyatakan Khaterine (2015), yang menyatakan bahwa ada beberapa pedoman untuk mengetahui apakah berat badan bayinya sudah naik dengan normal atau tidak jika mengonsumsi ASI, yaitu:Bayi yang baru lahir hingga usia 6 bulan, biasanya mengalami pertumbuhan sebesar 1,5-2,5 $\mathrm{cm}$ per bulan dan kenaikan berat badannya sebesar 0,5-1 kilogram setiap bulan. Diharapkan bayi memiliki berat yang dua kali lipat dengan berat badan saat diusia 6 bulan.Bayi berusia 6 bulan hingga 1 tahun, biasanya mengalami pertumbuhan sebesar $1 \mathrm{~cm}$ dan kenaikan berat badan sebanyak 0,5 kilogram setiap bulannya. Diharapkan berat badan bayi sudah 3 kali lipat dari berat badan bayi saat lahir diusia 1 tahun.

Bayi usia $0-6$ bulan yang tidak diberi ASI Eksklusif cenderung lebih banyak yang mengalami kelebihan berat badan dengan ratarata pertambahan/kenaikan 1.240 gram/bulan pada usia $0-3$ bulan. Hal ini dapat dinyatakan bahwa berat badan bayi yang mendapat ASI eksklusif lebih ringan dibanding bayi yang mendapat ASI non eksklusif/parsial sampai usia 6 bulan. Hal ini bukan berarti bahwa berat badan yang lebih besar pada bayi yang mendapat ASI non eksklusif/parsial lebih baik dibanding bayi yang mendapat ASI eksklusif (Norma, 2015).

Berdasarkan hasil penelitian dan pembahasan diatas peneliti berasumsi bahwa bayi yang diberi ASI parsial akan mendapat banyak karbohidrat sehingga zat gizi yang masuk tidak seimbang yang pada akhirnya akan menyebabkan kegemukan. Atau bisa juga disebabkan karena lemak yang terkandung di dalam ASI mudah dicerna dan diserap oleh bayi sehingga tidak terjadi penimbunan lemak yang berlebihan pada bayi yang diberi ASI Eksklusif.Dilihat hasil penelitian kenaikan ASI parsial lebih banyak dibanding ASI Eksklusif. Hasil penelitian ini menunjukkan berat badan bayi yang mendapat ASI lebih ringan dibanding bayi yang mendapat susu formula sampai umur 6 bulan. Hal ini bukan berarti bahwa berat badan yang lebih besar pada bayi yang mendapat susu formula lebih baik dibanding bayi yang mendapat ASI. Berat berlebih pada bayi yang mendapat susu formula justru menandakan terjadi kegemukan.

\section{KESIMPULAN DAN SARAN}

\section{Kesimpulan}

Berdasarkan hasil penelitian yang telah dilakukan terhadap ibu yang memiliki bayi usia7-12 bulan di Puskesmas Kalidoni Palembang pada tanggal $4-18$ April tahun 2018, dapat disimpulkan sebagai berikut:

1. Rata-rata pertambahan berat badan bayi yang diberi ASI Ekslusif adalah 4260 gram (95\% CI: 4182,24-4337,76) sedangkan ratarata pertambahan berat badan bayi yang diberi ASI Parsial adalah 4580 gram $(95 \%$ CI: 4461,23-4698,77).

2. Dari 15 responden yang bayinya diberikan ASI Eksklusif sebagian besar mengalami kenaikan berat badan normal sebanyak 10 responden $(66,7 \%)$, hal yang sama terjadi pada 15 responden yang diberikan susu formula sebagian besar mengalami kenaikan berat badan normal sebanyak 10 responden $(66,7 \%)$.

3. Adaperbedaan kenaikan berat badan pada bayi dengan pemberian ASI eksklusif dan ASI parsial di Puskesmas Kalidoni 
Palembang tahun 2018 dengan nilai $p$ value $0,000<\alpha(0,05)$.

\section{Saran}

\section{Bagi STIKES Mitra Adiguna Palembang}

Diharapkan dapat dijadikan sebagai bahan bacaan, pengetahuan, dan menambah wawasan tentang manfaat ASI eksklusif bagi kenaikan berat badan yang optimal bayi usia $0-6$ bulan.

\section{Bagi Puskesmas Kalidoni Palembang}

Diharapkan agar tenaga kesehatan khususnya bidan di Puskesmas Kalidoni Palembang lebih meningkatkan informasi terkait tentang maanfaat dan pentingnya pemberian ASI eksklusif untuk kenaikan berat badan bayi yang optimal.

\section{Bagi Ibu yang Mempunyai Bayi Usia 0-6 bulan}

Diharapkan dapat memberikan informasi bagi ibu yang mempunyai bayi berusia 0-6 bulan dalam memberikan gizi yang baik serta memberikan ASI secara Eksklusif.

\section{DAFTAR PUSTAKA}

Asih. 2016. Buku ajar asuhan kebidanan nifas dan menyusui.Jakarta : Trans Info Media

Candraswari, Risky. 2016. Berapa panjang dan berat normal bayi usia 0-12 bulan. http://www.hellosehat.com, diakses 27 Januari 2018

Dahlan, Sopiyudin. 2012. Statistik untuk kedokteran dan kesehatan: Deskriptif, Bivariat, dan Multivariat.Jakarta : Sagung Seto.

Damayanti, Dini Fitri. 2014. Tumbuh kembang bayi 0-6 bulan menurut status ASI di Puskesmas Telaga Biru Pontianak. Jurnal vokasi kesehatan volume 1 Nomor 3 Mei 2015.

Dinkes Kota Palembang. 2017. Cakupan pemberian ASI Eksklusif pada bayi usia 0-6 bulan. Palembang.
Irianto, Koes. 2014.Gizi seimbang dalam kesehatan reproduksi.Bandung : Alfabeta

Irsal, Fitra Sikrita. 2017. A to Z ASI dan Menyusui.Jakarta : Pustaka Bunda

Kemenkes. 2010. Peraturan Menteri Kesehatan Republik Indonesia Nomor 155/ Menkes/ Per/ 1/ 2010 tentang penggunaan kartu menuju sehat (KMS) bagi balita. Jakarta

Kemenkes. 2016. Profil Kesehatan Indonesia.http://www.kemenkes.go.id, diakses 25 Januari 2018

Marnoto, Budining Wirasatari. 2013. Pemberian susu formula pada bayi baru lahir.http://www.idai.or.id, diakses 25 Januari 2018

Munir, Miftahul. 2013. Pengaruh pemberian ASI eksklusif terhadap berat badan bayi umur 4-6 bulan di wilayah kerja Puskesmas Plumpang Kabupaten Tuban.

Norma, Asti. 2015. Perbedaan kenaikan berat badan pada bayi yang mendapat ASI Eksklusif dengan ASI parsial di Puskesmas Jetis Kota. Jurnal JNKI Vol.3 No.2 Tahun 2015.

Notoatmodjo, Soekidjo. 2012. Metode penelitian kesehatan.Jakarta : Rineka Cipta.

Prasetyowati, Yuni. 2015.Studi Komparasi Kenaikan Berat Badan Pada Bayi (0-6 Bulan) Yang Diberi Asi Eksklusif Dengan Bayi Yang Diberi Susu Formula. Vol.1,No.1, Desember 2015

Puskesmas Kalidoni Palembang. 2017. Jumlah bayi baru lahir dan bayi yang mengalami kenaikan berat badan dari tahun 2015-2017. Palembang

Saleha, Siti. 2009. Asuhan kebidanan pada masa nifas. Jakarta : Salemba Medika

Sulistyoningsih, Hariyani. 2012. Gizi untuk kesehatan ibu dan anak. Yogyakarta : Graha Ilmu 
Utami, Wiwik. 2015.Studi Komparasi Kenaikan Berat Badan Pada Bayi (0-6 Bulan) Yang Diberi Asi Eksklusif Dengan Bayi Yang Diberi Susu Formula. Vol.1,No.1, Desember 2015

Walyani, Elisabeth Siwi. 2015. Perawatan Kehamilan dan Menyusui Anak Pertama Agar Bayi Lahir dan Tumbuh Sehat. Yogyakarta : Pustaka Bar Press.

Yenie, Helmi. 2015. Studi komparatif pemberian ASI Eksklusif dan pemberian PASI terhadap pertambahan berat dan panjang badan pada bayi umur 6 bulan. 